1 Holmberg C, Perheentupa J, Launiala K, Hallman N. Congenital chloride diarrhoe genital chloride diarrhoea; clinical analysis

2 Lubani MM, Doudin KI, Sharda DC, et al. Congenital chloride diarrhoea in Kuwaiti children. Eur $\mathcal{F}$ Pediatr 1989;148:333-6.

3 Kagalwalla AF. Congenital chloride diarrhoea; a study in arab children. $\mathcal{f}$ Clin Gastrenterol 1994;19:36-40.
4 Hoglund P, Sistonen P, Norio R, et al. Fine mapping of congenital chloride diarrhoea gene by linkage disequilibrium. Am f Hum Genet 1995;57:95-102.

5 Lundkvist K, Anneen G, Esscher T, et al. Surgical implication of congenital chloride diarrhoea. Z Kinderchir 1983;38:217-9. 6 Kirkinen P, Jouppila P. Prenatal ultrasonic findings in congenital chloride diarrhoea. Prenat Diagnose 1984;4:457-
61.

\title{
An unusual cause of leg ulceration
}

\author{
D Banerjee, J Grey, K G Harding
}

A 46-year-old man was referred with a 2-year history of non-healing ulcers on both lower limbs. He had suffered two episodes of deep vein thrombosis, at the ages of 7 and 28 years. He was subsequently admitted to hospital for treatment of pulmonary embolism at the age of 30 . A year earlier, he had suffered an uncomplicated inferior wall myocardial infarction. On examination, he had multiple superficial ulcers on both his legs in the gaiter areas (figure). The surrounding skin showed signs of advanced venous insufficiency in the form of venous eczema, lipodermatosclerosis and pigmentation. Duplex imaging of his venous system revealed extensive bilateral post-phlebitic changes. His only medication was warfarin, which he had been advised to take lifelong. His 18-year-old son was also diagnosed to have a deep vein thrombosis and subsequent investigations revealed two of his three children to be suffering from the same condition.

\section{Wound Healing Research Unit, University of Wales College of Medicine, Cardiff CF4 4XN, Wales, UK \\ D Banerjee J Grey \\ K G Harding}

Accepted 2 September 1998

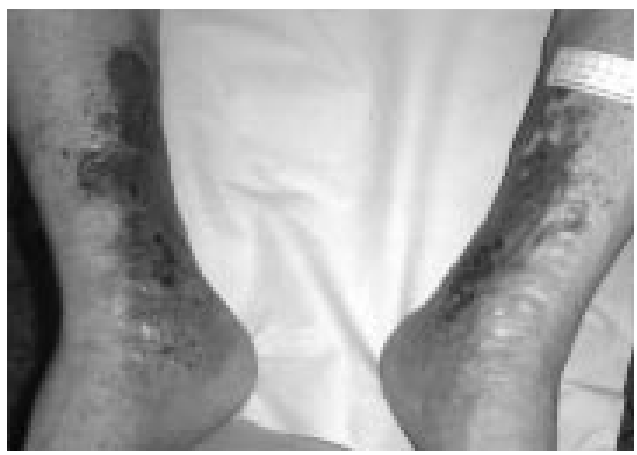

Figure The patient's legs

\section{Questions}

1 What is the underlying condition?

2 How is this condition managed?

3 How should the ulcers be treated? 


\section{Answers}

QUESTION 1

This patient was found to have hereditary protein $\mathrm{S}$ deficiency (PSD). It is an autosomal dominant disorder, associated with an increased risk for developing thrombosis in heterozygotes ${ }^{1}$; hence the higher prevalence among ethnic groups practising consanguinity. The thrombotic episodes are rare before the age of 15 but it has been reported in a 10-yearold boy. ${ }^{2}$ The acquired form of PSD can be due to various disorders including advanced malignancy, chicken pox and other viral infections (eg, HTLV-I).

Among the known plasma protein deficiencies associated with venous thrombosis, protein $\mathrm{S}$ and protein $\mathrm{C}$ deficiencies are the commonest. ${ }^{4}$ Protein $\mathrm{S}$ is the vitamin K-dependent cofactor of activated protein $\mathrm{C}$ (APC) which functions as a potent anticoagulant by degrading activated factors $\mathrm{V}$ and VIII in a $\mathrm{Ca}^{2+}$ and phospholipid-dependent reaction. ${ }^{5}$ Protein $S$ exists as two forms in plasma, either free and functionally active or complexed with $\mathrm{C} 4 \mathrm{~b}$-binding protein and inactive. Inherited resistance to APC was recently discovered as a cause of familial thrombophilia and is now known to be the most common genetic risk factor for venous thrombosis. APC resistance is usually associated with a single point mutation in the factor $\mathrm{V}$ gene, which results in substitution of arginine at position 506 by glutamine. The mutation renders factor Va partially resistant to degradation by APC, which leads to a hypercoagulable state and increased risk of venous thrombosis. The previously known inherited deficiencies of antithrombin, protein S, or protein $\mathrm{C}$, are, in western societies, together found in less than $10-15 \%$ of thrombosis patients, whereas APC resistance is present in $20-60 \%$ of the patients. ${ }^{6}$

QUESTION 2

In young patients with recurrent venous thromboembolism in the absence of obvious predisposing factors, it is important to exclude inherited plasma protein deficiencies of protein $\mathrm{S}$, protein $\mathrm{C}$, antithrombin III, plasminogen and fibrinogen.

1 Petersen EJ, Allaart RC, Meuwissen OJ. A Dutch family with hereditary protein $\mathrm{S}$ deficiency. Neth $\mathrm{f} \mathrm{Med}$ 1989;34:243-50

2 Zoller B, He X, Dahlback B. Homozygous APC-resistance combined with inherited type I protein $\mathrm{S}$ deficiency in a young boy with severe thrombotic disease. Thromb Haemostasis 1995;73:743-5.

3 Schwartz J, Gonzalez 3, Rosenberg R, et al. Cutaneous T-cell lymphoma, tropical spastic paraparesis, cerebral T-cell lymphoma, tropical spastic paraparesis, cerebral vasculitis, and protein S deficiency in

4 Gladson CL, Scharrer I, Hach V, Beck KH, Griffin JH. The Gladson CL, Scharrer I, Hach V, Beck $\mathrm{KH}$, Griffin JH. The
frequency of type I heterozygous protein S and protein $\mathrm{C}$ deficiency in 141 unrelated young patients with venous thrombosis. Thromb Haemostasis 1988;59:18-22.

\section{Learning points}

- among the known plasma protein deficiencies associated with venous thrombosis, protein $S$ and protein $\mathrm{C}$ deficiencies are the commonest

- protein $S$ deficiency is an autosomal dominant disorder of the clotting system resulting in a hypercoagulable state; an acquired form of the condition can result from various systemic disorders

- protein S deficiency should be suspected in any young patient suffering from deep vein thrombosis or other thrombotic episode and a thrombophilia screen should be performed.

- a thorough family history should be obtained and close family members screened

- recurrent venous thromboses are common in such patients, starting at a very young age, and current practice advocates life-long anticoagulant prophylaxis

- in patients who develop post-phlebitic changes in their limbs, including ulceration, treatment comprises compression and topical wound care

Treatment is predominantly prophylactic, in the form of long-term oral anticoagulation with warfarin. Where its use is contraindicated, for example, in pregnancy, or in the event of warfarin-induced skin reactions, heparin is a suitable alternative. At present, there is lack of consensus regarding the duration of treatment. Current practice seems to favour life-long warfarin therapy.

QUESTION 3

The ulcers are initially treated with topical iodine-impregnated dressing and graduated compression therapy. Venous eczema is treated effectively with topical steroid preparations, usually over 10-12 weeks. After the first few weeks of healing, the compression therapy should be changed to a four-layer bandage system. ${ }^{7}$ The ulcers in this patient had healed satisfactorily by the end of 12 weeks of treatment.

\section{Final diagnosis}

\section{Protein S deficiency.}

Keywords: protein S deficiency; venous thrombosis

5 Wiesel ML, Charmantier JL, Freyssinet JM, Grunebaum L, Schuhler S, Cazenave JP. Screening of protein S deficiency using a functional assay in patients with venous and arterial thrombosis. Thromb Res 1990:58:461-8.

6 Dahlback B, Zoller B, Hillarp A. Inherited resistance to activated protein $C$ caused by presence of the Fv:Q506 allele as a basis of venous thrombosis. Haemostasis 1996;26(suppl 4):301-14.

7 Nelson EA, Harper DR, Ruckley CV, et al. A randomised trial of single-layer and multi-layer bandages in the treatment of chronic venous ulceration. Phlebology 1995; (suppl 1):915-6. 


\title{
A new diabetic patient with an abdominal mass
}

\author{
Boji Varghese, W P Stephens
}

A 47-year-old woman was referred to the new patient diabetic clinic with typical symptoms of hyperglycaemia. On routine abdominal examination, a mass was found on the left side of the abdomen which was ballottable and bimanually palpable. There was a history of 'benign retinal tumour' several years ago which did not need active treatment. Further enquiry revealed this to have been a retinal angioma. Routine laboratory tests on blood and urine were unremarkable except for findings of diabetes mellitus. She went on to have ultrasound scan followed by computed tomography (CT) of the abdomen (figure).
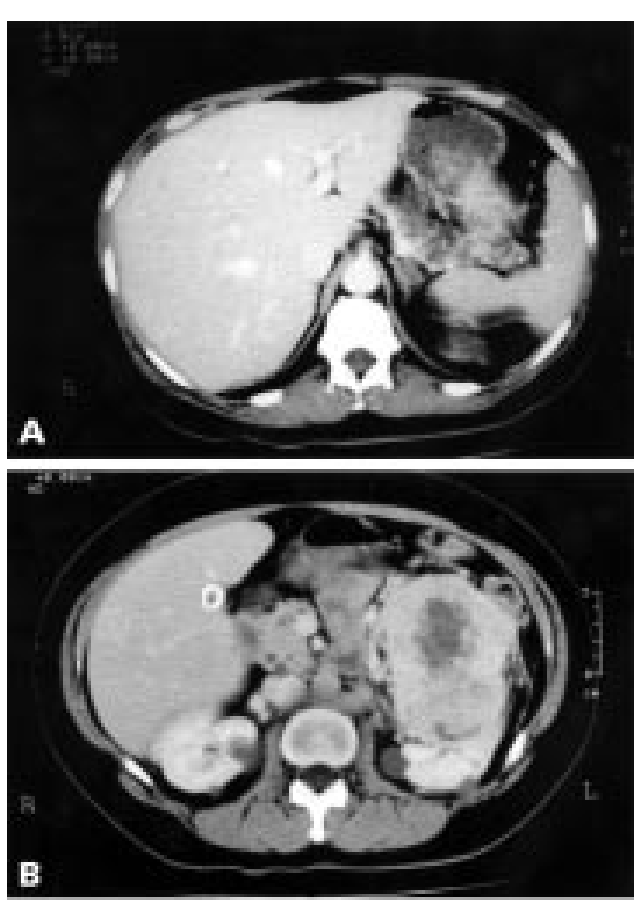

Department of Medicine, Trafford General Hospital, Moorside Road, Davyhulme,

Manchester M41 5SL, UK

B Varghese W P Stephens

Correspondence to Dr B Varghese, 13 Reeves Court, Canterbury Gardens, Salford, Manchester M5 2AE, UK

Accepted 2 September 1998

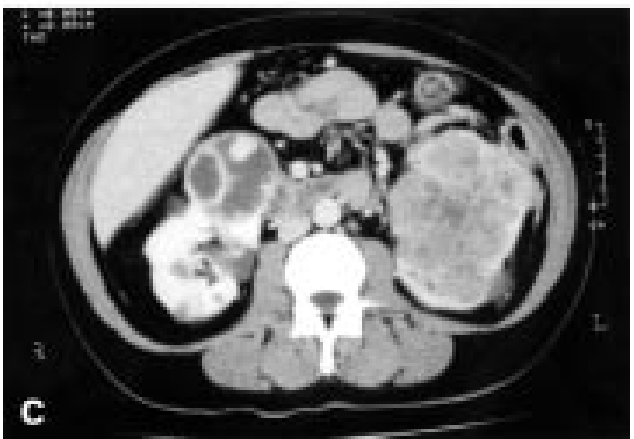

Figure $\mathrm{CT}$ scan of the abdomen

\section{Questions}

1 What is the main abnormality seen on the CT scan and what is the radiological diagnosis?

2 What other abnormalities are present on the CT scan?

3 What condition does the patient have?

4 What other abnormalities may occur in this condition? 